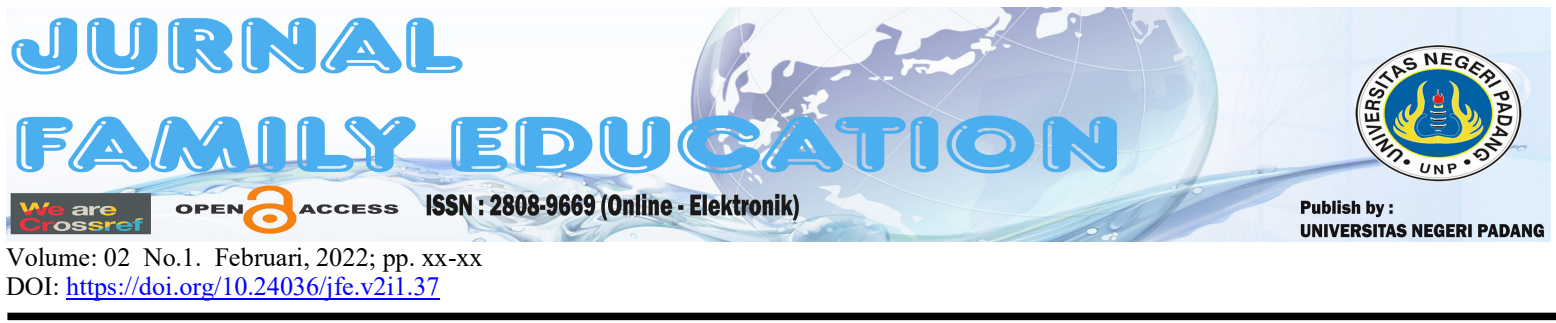

\title{
Persepsi Masyarakat Terhadap Pemberdayaan Perempuan Pada Program Pnm Mekaar Dijorong Kotobaru Air Dingin Kab. Solok
}

\author{
Wiwi Gusmita, Solfema \\ Universitas Negeri Padang \\ * e-mail: wiwigusmita02@gmail.com
}

\begin{abstract}
Non formal education is education that is very important to exist in the community. One form of part of education outside of school is women's empowerment which is an effort to improve the abilities and skills of women where women are always considered weak so that an empowerment is needed. There are 3 indicators in this study: 1. Financial management, 2. Timeliness 3. Borrowing rules. By using descriptive quantitative research methods. The results of this study indicate that the empowerment of women through PT PNM Mekaar can be said to have been achieved well.
\end{abstract}

Keywords: women empowerment, PT PNM Mekaar

\section{PENDAHULUAN}

Pendidikan Luar Sekolah adalah segala upaya pendidikan yang sistematis dan terorganisir, dilaksanakan di luar sistem persekolahan, dengan maksud untuk mengembangkan potensi yang dimiliki oleh peserta didik sesuai dengan usia dan kebutuhannya. (Nurhayati, 2012) Selain itu, berdasarkan beberapa batasan tentang pengertian Pendidikan Luar Sekolah, maka dapat diambil kesimpulan pula bahwa Pendidikan Luar Sekolah merupakan setiap kegiatan yang dilakukan di luar jalur pendidikan formal dimana terdapat proses belajar sehingga seseorang yang menjadi peserta belajar akan mendapatkan pengetahuan, pemahaman, keterampilan dan bimbingan sehingga dapat tercapai tujuan belajarnya.

Pendidikan Luar Sekolah tentu memiliki keterkaitan dengan program pemberdayaan, salah satunya adalah pemberdayaan perempuan . dikarenakan dalam suatu program pemberdayaan yang dilakukan tidak selalu berpatokan pada mengembangan pengetahuan, keterampilan, maupun sarana dan prasarana, suatu program pemberdayaan perempuan agar pelaksanaan terlaksana dengan baik serta dapat mencapai tujuan, maka harus mempunyai suatu fondasi kuat, yang harus dimiliki oleh masyarakat sasaran. (Solfema, 2021)Yang berupa sebuah upaya penyadaran, perubahan tingkah laku, serta pola pikir. Hal ini tentu sangat terkait dengan kajian pendidikan luar 
sekolah menyangkut pendekatan maupun metode yang biasanya sasaran dari pemberdayaan ini adalah orang dewasa begitu juga pada program pemberdayaan perempuan.

Pemberdayaan perempuan merupakan upaya yang dapat meningkatkan kemampuan serta keterampilan kaum wanita. Dalam kehidupan bermasyarakat selain sebagai makhluk individu wanita juga merupakan sebagai makhluk sosial. (Indah, 2016). Hal ini berarti wanita juga berhak untuk menunjukkan eksistensinya didalam masyarakat, sehubung dengan hal itu maka untuk beberapa hal wanita dibebaskan bergerak didalam masyarakat, karena pada kenyataannya wanita lebih paham akan dirinya dan menyadari bahwa dirinya juga mampu untuk bekerja dalam hal membantu memenuhi kebutuhan rumah tangga (Prantiasih, 2014). Pemberdayaan perempuan tidak hanya dibidang sosial, politik, pendidikan dan budaya tapi juga dibidang ekonomi, Keikutsertaan perempuan dalam dunia kerja berpengaruh sangat besar untuk kesejahteraan keluarga. Khususnya dibidang ekonomi, wanita ikut bekerja tidak lain karena pendapatan laki-laki tidak mencukupi untuk kehidupan sehari-hari. Apalagi dengan keadaan lingkungan yang tidak menguntungkan. Keadaan demikianlah yang membuat perempuan memiliki peranan ganda yaitu peranan domestik seperti mengurus rumah tangga dan peranan publik untuk bekerja diluar rumah. Pada dasarnya perempuan yang tinggal diwilayah pedesaan dengan taraf perekonomian rendah. (Saugi \& Sumarno, 2015) Peran ganda tidak bisa dikatakan sebagai sesuatu hal yang asing lagi bagi perempuan-perempuan golongan ini, sejak kecil mereka sudah dilatih untuk bekerja, mereka tidak bisa bermain layaknya remaja-remaja seusia mereka karena mereka sudah berperan dan sudah diberi kewajiban untuk membantu memenuhi kebutuhan ekonomi keluarga. Salah satu bentuk pekerjaan yang bisa dilakukan oleh perempuan yaitu bisa dengan membangun usaha dirumah namun tidak semua perempuan bisa membangun usaha disebabkan karena kekurangan biaya, untuk mengatasi permasalahan ini pemerintah memberikan solusi dengan memberikan pinjaman tanpa jaminan kepada para perempuan melalui PT Permodalan Nasional Madani (Persero).

Program PT PNM Mekaar ini merupakan bagian dari pemberdayaan perempuan dikarenakan PT PNM ini ditujukan untuk wanita-wanita yang bisa dikatakan belum mencapai kesejahteraan dalam usaha usaha mikro, baik untuk yang sedang menjalankan usaha ataupun untuk yang akan memulai usaha Program kerja yang dimiliki PT PNM ini bertujuan untuk mensejahterakan serta membimbing masyarakat agar dapat mencapai kehidupan yang lebih baik.(Sekar Inten Mulyani, 2020)

Berdasarkan hasil pengamatan peneliti dijorong kotobaru kenagarian air dingin, dari tgl 19 april - 02 mei terlihat kegiatan pemberdayaan perempuan terlihat masih belum maksimal, adapun fenomena yang peneliti temukan, sebagai berikut: 1.Terlihat bahwa banyak masyarakat menerima dengan baik kehadiran PNM Mekaar ini. Meskipun banyak peraturan yang harus dipatuhi oleh 
setiap nasabah salah satu nya tentang pengelolaan keuangan. 2. Kebijakan dari PNM Mekaar tentang rapat, yaitu rapat diadakan setiap minggu dan nasabah diwajibkan untuk hadir. nasabah harus datang setiap minggunya jika mereka tidak datang maka akan ada sanksi untuk mereka. 3 . kebanyakan dari perempuan yang melakukan pinjaman disini menyalahgunakan uang yang diberikan mereka tidak menggunakan uang tersebut sebagaimana tujuan dari peminjaman modal ini. Sehingganya terdapat banyak masalah saat mereka akan membayar angsuran setiap minggunya, hal ini diduga karena kurangnya pelatihan yang diberikan oleh pihak PNM Mekaar ini, pihak PNM Mekaar ini tidak terlalu memperhatikan nasabahnya, hingga pada akhirnya uang yang dipinjam kan disalahgunakan.

Berdasarkan fenomena tersebut peneliti menduga bahwa keberhasilan suatu kegiatan pemberdayaan tidak terlepas dari persepsi positive dari masyarakat itu sendiri. Persepsi masyarakat terhadap kegiatan pemberdayaan perempuan melalui program PNM Mekaar dapat dilihat dari pandangan anggota dan realisasi terhadap kegiatan pada program tersebut. pandangan masyarakat itu menunjukkan tidak baik, kurang baik, cukup baik, baik, sangat baik. Esier (dalam mulyadi, 2018: 152) menyatakan bahwa "persepsi adalah pandangan seseorang terhadap sesuatu objek yang dilihat berdasarkan situasi, waktu dan tempat dari pandangan tersebut akan melahirkan suatu perbuatan atau tindakan yang merupakan manifestasi dari penilaian yang diberikan terhadap sesuatu".

Sesuai dengan permasalahan dalam penelitian, adapun tujuan yang ingin dicapai adalah untuk: 1. Untuk mengetahui persepsi masyarakat tentang pengelolaan keuangan di PNM Mekaar. 2.Untuk mengetahui persepsi masyarakat tentang keharusan anggota mengikuti rapat setiap minggunya. 3.Untuk mengetahui persepsi masyarakat tentang aturan peminjaman yang diharuskan bertahap.

\section{METODE}

Penelitian ini termasuk dalam penelitian kuantitatif dengan jenis deskriptif. yang akan menggambarkan, mengungkapkan dan menafsirkan data sebagaimana adanya (Iyus Jayusman, 2020). Populasi dalam penelitian ini adalah para wanita prasejahtera yang mengikuti program pnm mekaar sebanyak 120 orang, dan sampel dalam penelitian ini sebanyak 33 orang. Teknik yang digunakan untuk mengumpulkan data dalam penelitian ini adalah angket, sedangkan alat pengumpul datanya adalah koesioner.

Prosedur penyusunan instrumen dalam penelitian ini dengan dilakukannya penyusunan angket dan melakukan uji coba. Analisis data dalam penelitian ini yaitu untuk melihat persepsi masyarakat terhadap pemberdayaan perempuan pada program pnm mekaar dijorong kotobaru kenagarian air dingin. Dengan menggunakan rumus statistik persentase dan product moment. 


\section{HASIL DAN PEMBAHASAN}

Persepsi angggota PNM Mekaar tentang pengelolaan keuangan bagi nasabah di PNM Mekaar Jorong Koto Baru Kenagarian Air Dingin Kec. Lembah Gumanti

Alternatif jawaban responden dengan skor tertinggi ditunjukkan pada jawaban selalu yaitu 4,42 yang berarti bahwa nasabah di pnm mekaar tidak menggunakan modal yang dipinjamkan untuk modal usaha. Apabila data pada tabel tersebut dilihat melalui diagram, maka skor kemunculan jawaban responden akan terlihat seperti gambar berikut ini.

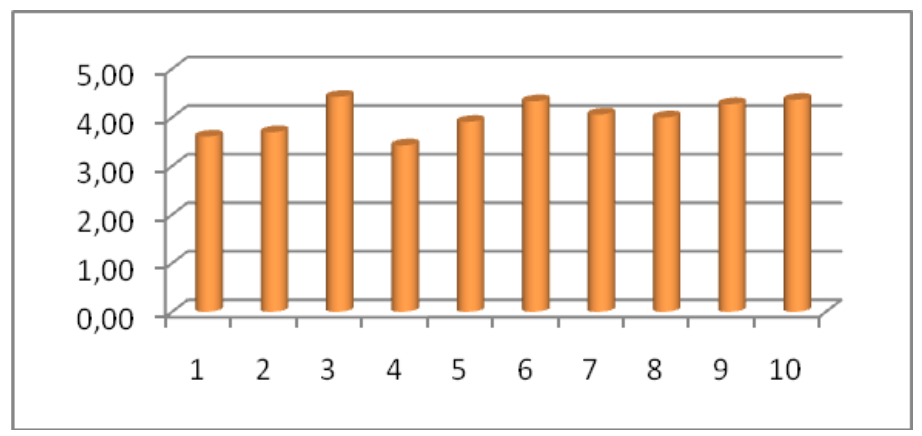

Gambar 1 : diagram rekapitulasi persepsi masyarakat tentang pengelolaan keuangan

Berdasarkan data pada gambar di atas dapat diketahui bahwa pengelolaan keuangan tergolong pada kategori setuju Hal tersebut dapat dilihat dari hasil persentase jawaban responden terbanyak pada alternatif setuju. Sehingga dapat disimpukan bahwa pengelolaan keuangan disini sudah terkelola dengan baik karena memang program ini di khususkan untuk perempuanperempuan prasejahtera sehingga pengelolaan nya sudah dilakukan dengan semaksimal mungkin.

Persepsi anggota PNM Mekaaar tentang ketepatan waktu bagi nasabah di PNM Mekaar jorong koto baru

Alternatif jawaban responden dengan skor tertinggi ditunjukkan pada jawaban selalu (yaitu 4,45) yang berarti bahwa nasabah di pnm mekaar memang diharuskan untuk datang tepat waktu , tidak boleh ada yang izin dan juga bagi petugas nasabah yang sering terlambat Apabila data pada tabel tersebut dilihat melalui diagram, maka skor kemunculan jawaban responden akan terlihat seperti gambar berikut ini.

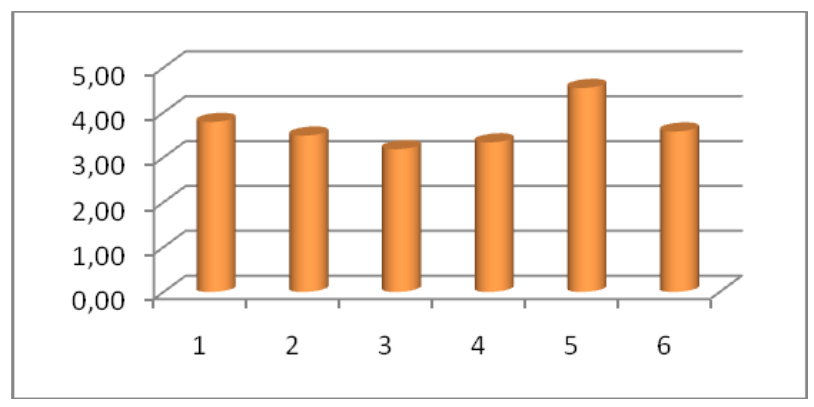


Gambar 2 : diagram rekapitulasi persepsi masyarakat tentang ketepatan waktu

Berdasarkan data pada gambar di atas dapat diketahui bahwa aspek ketepatan waktu tergolong pada kategori setuju Hal tersebut dapat dilihat dari hasil skor jawaban responden terbanyak pada alternatif setuju. Sehingga dapat disimpukan bahwa memang keidisplinan waktu bagi petugas dan anggota dari PNM Mekaar ini sangat diperhatikan tidak ada yang boleh terlambat dan tidak hadir saat rapat.

\section{Persepsi anggota PNM Mekaar tentang aturan peminjaman bagi nasabah di PNM Mekaar} jorong koto baru

Alternatif jawaban responden dengan skor tertinggi ditunjukkan pada jawaban selalu (yaitu 4,45) yang berarti bahwa nasabah di pnm mekaar memang keberatan dengan aturan peminjaman yang berlaku. Apabila data pada tabel tersebut dilihat melalui diagram, maka skor kemunculan jawaban responden akan terlihat seperti gambar berikut ini.

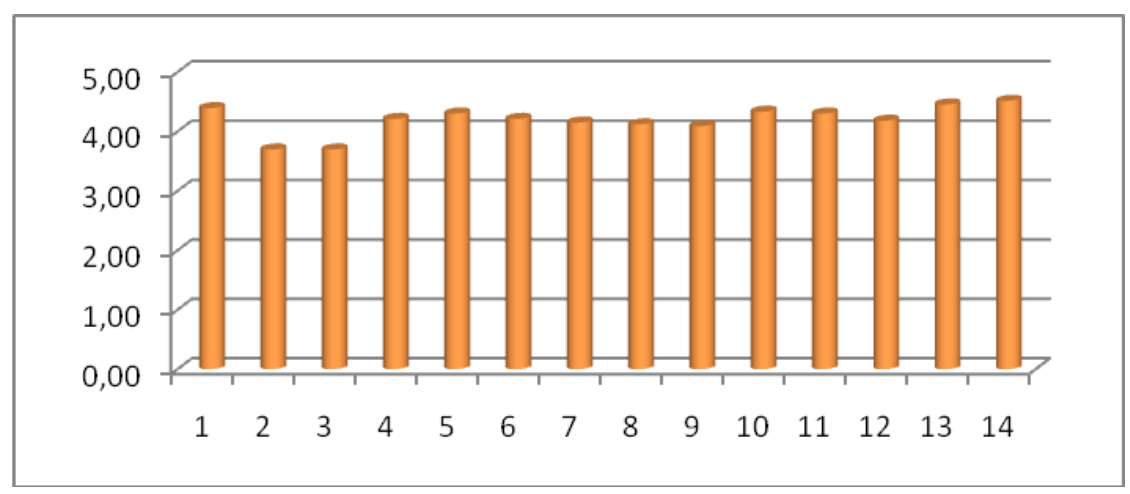

Gambar 3 : diagram rekapitulasi persepsi masyarakat tentang aturan peminjaman

Gambar diatas dapat disimpulkan dari jawaban yang diberikan responden terhadap sub variabel aturan pinjaman dikategorikan setuju, sehinggga dapat disimpulkan bahwa aturan pinjaman di PNM mekaar ini masih belum bisa diterima dengan baik oleh masyarakat.

\section{Pembahasan}

\section{Persepsi Angggota PNM Mekaar Tentang Pengelolaan Keuangan Bagi Nasabah Di PNM} Mekaar Jorong Koto Baru Kenagarian Air Dingin Kec. Lembah Gumanti

Temuan dari Persepsi angggota PNM Mekaar tentang pengelolaan keuangan bagi nasabah menunjukkan setuju artinya pengelolaan keuangan disini sudah terkelola dengan baik karena memang program ini di khususkan untuk perempuan-perempuan prasejahtera sehingga pengelolaan nya sudah dilakukan dengan semaksimal mungkin. Maka karena inilah PNM Mekaar ini semakin maju dan semakin banyak dari masyarakat yang memilih pinjaman di disini. 
Pengelolaan keuangan jika dilihat dari aspek bimbingan teknis penggunaan keuangan, seharusnya dalam pengelolaan keuangan ini dibimbing dan diarahkan dengan tegas oleh petugas sehingganya para nasabah mampu mengelola keuangan mereka dengan baik sehingga nantinya dapat tercapai pemberdayaan perempuan yang baik. (Sabiq, Al, Rizqi, \& Ananda, 2001).sebagai mana dikemukan oleh Devas (2007:279) pengelolaan keuangan berarti mengurus dan mengatur keuangan dengan prinsip-prinsip pengelolaan keuangan yaitu tangggung jawab, Mampu memenuhi kewajiban keuangan, kejujuran, hasil guna, pengendalian. Hal ini dimaksudkan agar masyarakat atau nasabah dari pnm mekaar ini mampu mengelola keuangan mereka dengan sebagaimana semestinya sehingga nantinya bisa tercapai tujuan dari PT PNM Mekaar itu sendiri.

Pengelolaan keuangan jika dilihat aspek penggunaan modal, penggunaan modal ini berhubungan dengan seberapa bijaknya nasabah dalam mengelola keuangan mereka tentunya harus dibantu oleh petugas pnm mekaar itu sendiri, berdasarkan hasil dari penelitian yang didapat petugas hanya melakukan survey dari jauh, sehingganya tidak semua dari nasabah tersebut yang menunjukkan hak milik mereka. Sebagaimana yang dikemukan oleh Horne dalam (Kasmir 2010) pengelolaan keuangan adalah segala aktivitas yang berhubungan dengan perolehan, pendanaan, dan pengelolaan aktiva dengan beberapa tujuan menyeluruh.

Dari pembahasan yang telah dipaparkan diatas, dapat diambil simpulan bahwa pengelolaan mempengaruhi persepsi seseorang terhadap suatu kegiatan. (Ramadani, Suci \& Sunarti, 2018) Hal ini terlihat dari mayoritas responden mereka menyatakan bahwa mendapat manfaat dari pinjaman ini. Namun karena juga ada kesalahan dalam pengelolaan keuangan maka berdampak kurang baik terhadap mereka Semakin banyak keuntungan yang didapat maka akan semakin baik manfaat atau keuntungan yang diperoleh, maka semakin baik persepsi seseorang terhadap suatu kegiatan yang dilakukan. Dalam penelitian ini pengelolaan keuangan nya sudah dilakukan dengan baik, karena memang program ini sudah dirancang dengan sebaik mungkin sebelum diturunkan kemasyarakat.

\section{Persepsi anggota PNM Mekaaar tentang ketepatan waktu bagi nasabah di PNM Mekaar jorong koto baru}

Temuan dari Persepsi angggota PNM Mekaar tentang ketepatan waktu bagi nasabah di PNM Mekaar di Jorong Koto Baru Kenagarian Air Dingin Kec. Lembah Gumanti menunjukkan setuju artinya bahwa memang kedisplinan waktu bagi petugas dan anggota dari PNM Mekaar ini sangat diperhatikan tidak ada yang boleh terlambat dan tidak hadir saat rapat.

Ketepatan waktu dalam penelitian ini berkaitan dengan ketepatan waktu bagi para petugas nasabah dalam memberikan pelayanan, karena datang tepat waktu merupakan hal yang paling

penting dalam suatu kegiatan Temuan dari persepsi anggota PNM Mekaar terhadap ketepatan 
waktu menunjukkan setuju, artinya ketepatan waktu harus ditingkatkan lagi dikarenakan menurut data yang didapat petugas dari nasabah juga sering terlambat, sebagaimana yang diungkapkan oleh Suwardjono ketepatan waktu merupakan "tersedianya informasi bagi pembuat keputusan pada saat dibutuhkan sebelum informasi tersebut kehilangan kemampuan untuk mempengaruhi sebuah keputusan”. Ketepatan waktu (timeliness) merupakan salah satu faktor penting dalam penyajian suatu informasi yang relevan. Informasi akan mempunyai manfaat jika disampaikan tepat waktu kepada para pemakainya untuk pengambilan keputusan.(Syahputri, Kananto, \& Ak, 2020) Dari data yang didapatkan menunjukkan pada kategori setuju ini berarti dengan aturan yang berlaku seperti tidak boleh datang terlambat, tidak bleh izin saat rapat perminggunya, serta juga para petugas dari nasabah itu juga sering terlambat hal ini juga berpengaruh terhadap persepsi nasabah itu sendiri. semakin seringnya petugas nasabah terlambat maka juga akan mengubah persepsi dari masyarakat itu sendiri yang mengakibatkan mereka tidak terlalu mematuhi aturan dari PNM Mekaar itu sendiri.

dari pembahasan yang telah dijelaskan diatas, dapat ditarik kesimpulan bahwa ketepatan waktu merupakan ketepatan dalam melaksanaan suatu pelayanan sehingga dapat diselesaikan dalam kurun waktu yang telah ditentukan. Berdasarkan data yang didapat nasabah di PNM Mekaar ini ketepatan waktu sudah berjalan dengan baik namun untuk kehadiran dari petugas nasabah perlu ditingkatkan lagi.

\section{Persepsi anggota PNM Mekaar tentang aturan pinjaman bagi nasabah di PNM Mekaar jorong koto baru}

Temuan dari Persepsi Angggota PNM Mekaar Tentang Aturan Peminjaman Bagi Nasabah Di PNM Mekaar Jorong Koto Baru Kenagarian Air Dingin Kec. Lembah Gumanti menunjukkan setuju artinya Aturan-aturan yang ditetapkan oleh pihak PNM Mekaar tersebut belum bisa diterima dengan baik oleh masyarakat.

Pinjaman adalah satu jenis hutang yang dapat melibatkan semua jenis benda berwujud walaupun biasanya lebih sering diidentik dengan pinjaman moneter. Peminjam awalnya akan menerima sejumlah pinjaman baik berupa uang atau benda dari pemberi hutang yag akan dibayar kembali, seringkali dalam bentuk aturan yang berkala, kepada pemberi hutang. Jasa ini seringkali disebut sebagai bunga dari sipemberi hutang, pihak peminjam juga dapat memperoleh batasan yang diberikan dalam bentuk syarat pinjaman. (Astariyani, 2020) Aturan pinjaman merupakan hal-hal yang harus dipatuhi oleh setiap anggotanya. Dalam penelitian ini aturan pinjaman yang juga merupakan syarat-syarat yang harus diikuti oleh setiap nasabah, namun aturan yang berlaku ini belum dapat diterima dengan baik dikalangan masyarakat dikarenakan terlalu memberatkan 
Wiwi Gusmita, Solfema

bagi masyarakat hal ini berdasarkan dari jawaban responden yang berada pada skor 4,1 dengan kategori setuju.

Dalam kamus KBBI secara bahasa aturan merupakan sebuah capaian dari suatu perbuatan yang mengatur cara (ketentuan, patokan, petunjuk, perintah) yang sudah ditetapkan untuk dapat dituruti. Aturan dapat diartikan sebagai pedoman supaya manusia bisa hidup secara tertib dan teratur. Aturan peminjaman merupakan suatu pedoman bagi sebuah program dengan tujuan agar terbentuknya sebuah program yang berkualitas, pada PNM Mekaar ini menerapkan kebijakan berupa pinjaman dapat dilakukan secara berurutan mulai dari nominal rendah sampai nominal tinggi, aturan ini tidak dapat diganggu gugat, dan setiap nasabah harus mematuhi aturan ini.

Bagaimana masyarakat bisa memahami dan mencapai suatu kemandirian jika mereka terikat dengan aturan-aturan yang mereka sendiri dengan keberatan, mereka merasa keberatan dengan beberapa aturan pinjaman yang berlaku di PNM Mekaar ini. Dalam penelitian ini pinjaman yang dimaksudkan adalah nasabah menerima sejumlah uang dari PT PNM Mekaar yang kemudian akan dibayar dengan angsuran perminggunya dengan syarat dan ketentuan yang berlaku. Ada beberapa atuan yang harus diikuti oleh nasabah apabila ingin melakukan pinjaman di mekaar ini diantaranya, Peminjaman harus dilakukan secara bertahap, pinjaman bisa dilakukan jika memiliki usaha mikro dan lain sebagainya.

Pemberdayaan perempuan akan tercapai apabila perempuan itu sendiri mampu mandiri dan tidak bergantung pada oranglain. Dalam aspek ini pemberdayaan perempuan belum bisa dikatakan tercapai dikarenakan masih banyak kendala yang didapat, sehingga perempuan belum bisa mandiri sepenuhnya

\section{PENUTUP}

\section{kesimpulan}

Menurut hasil penelitian dan pembahasan tentang Persepsi Masyarakat Terhadap Pemberdayaan Perempuan Pada Program PNM Mekaar di Jorong Koto Baru Kenagarian Air Dingin Kab. Solok, dapat disimpulkan sebagai berikut: 1) pengelolaan keuangan yang dipinjam kepada masyarakat sudah terkelola dengan baik.pengelolaan keuangan ini memang sudah di siapkan dengan baik, ini dibuktikan dengan jawaban setiap item pernyataan yang diberikan responden penelitian cenderung menjawab setuju. 2) ketepatan waktu sudah bisa dikatakan baik, kehadiran anggota tepat waktu dan juga petugas nya sudah tepat waktu, hal ini dibuktikan dengan jawaban setiap item pernyataan yang diberikan responden penelitian cenderung menjawab setuju.. 3) ada beberapa aturan yang memang dirasa memberatkan nasabah namun secara keseluruhan aturan peminjaman sudah terkelola dengan baik. 


\section{Saran}

dari kesimpulan diatas, maka penulis memberikan beberapa saran sebagai berikut : 1) dari hasil yang didapat pengelolaan keuangan sudah baik namun harus lebih ditingkatkan lagi dikarenakan belum semua dari nasabah mampu mengelola keuangan dengan baik 2) disarankan kepada petugas nasabah lebih mengefisien kan waktu supaya tetap disiplin waktu dikarenakan pada jawaban responden masih terdapat jawaban kurang setuju 3) disarankan untuk program PNM Mekaar ini suapaya tidak lagi menambah aturan peminjaman dikarenakan aturan yang sudah berlaku belum dapat diterima dengan baik oleh masyarakat.

\section{DAFTAR PUSTAKA}

Astariyani, P. M. N. L. G. (2020). Perjanjian pinjam meminjam uang dengan jaminan handphone yang dilakukan pada counter handphone *. 8(49), 832-847.

Indah, A. (2016). PERAN WANITA DALAM MENUNJANG PEREKONOMIAN KECAMATAN KALAWAT. (17).

Iyus Jayusman, O. A. K. S. (2020). STUDI DESKRIPTIF KUANTITATIF TENTANG AKTIVITAS BELAJAR MAHASISWA DENGAN MENGGUNAKAN MEDIA PEMBELAJARAN EDMODO DALAM PEMBELAJARAN SEJARAH. 7(1), 13-20.

Nurhayati, S. (2012). PENDIDIKAN LUAR SEKOLAH DAN PEMBANGUNAN MANUSIA INDONESIA. $1(1), 1-12$.

Prantiasih, A. (2014). Reposisi peran dan fungsi perempuan. (5).

Ramadani, Suci, I., \& Sunarti, V. (2018). HUBUNGAN ANTARA PENGELOLAAN LINGKUNGAN BELAJAR DENGAN PERKEMBANGAN SOSIAL ANAK USIA DINI MENURUT WALI MURID DI PAUD FALAMBOYAN PARIT MALINTANG KABUPATEN PADANG. 1. https://doi.org/10.24036/spektrumpls.v1i2.10284

Sabiq, M., Al, H., Rizqi, R. M., \& Ananda, N. A. (2001). PENGELOLAAN KEUANGAN DAN PENGEMBANGAN USAHA PADA USAHA MIKRO KECIL MENENGAH ( STUDI KASUS PADA UMKM MADU HUTAN LESTARI SUMBAWA ) and Development, Management Diversification This study aims to determine the financial management and business development ap. JURNAL MANAJEMEN DAN BISNIS, 2(1). Retrieved from http:/ / jurnal.uts.ac.id

Saugi, W., \& Sumarno, S. (2015). Pemberdayaan perempuan melalui pelatihan pengolahan bahan pangan lokal. Jurnal Pendidikan Dan Pemberdayaan Masyarakat, 2(2), 226. https://doi.org/10.21831/jppm.v2i2.6361

Sekar Inten Mulyani, A. (2020). PERAN PT PERMODALAN NASIONAL MADANI (PT PNM) DALAM PEMBIAYAAN PELAKU USAHA AGRIBISNIS DI KOTA TARAKAN. 3(April), 29-35.

Solfema. (2021). statistik pendidikan teori dan praktik dalam pendidikan luar sekolah (1st ed.; Kencana, ed.). jakarta: KENCANA.

Syahputri, L. L., Kananto, R. K. P., \& Ak, M. (2020). Analisi Faktor-Faktor Yang Mempengaruhi Ketepatan Waktu Pelaporan Keuangan (Studi Empiris pada Perusahaan Perbankan yang Terdaftar Di BEI Periode Tahun 2016-2019) Lia. 1-15. 